\title{
Management of sustainable development of the regions of Kazakhstan: problems and solutions
}

\author{
Zulfiya Magrupova, Gaukhar Koshebaeva, and Gulnara Abzalbek* \\ Karaganda Technical University, Karaganda, Republic of Kazakhstan
}

\begin{abstract}
The study presents the results of the implementation of the State Program for the Development of the Regions of the Republic of Kazakhstan until 2020. In the face of modern challenges, it becomes critically important to increase the self-sufficiency of the economy of the Republic of Kazakhstan on the basis of regional development. In order to comply with and take into account national interests, it will be important to launch the adopted State Program for the Development of Regions by 2025. State regulation of territorial development is aimed at disclosing the industrial potential of individual regions and territories of the Republic of Kazakhstan. Taking into account the processes of regionalization taking place in the economy, the prerequisites for the formation of a regional structure of industrial production are considered in the work. The results of the implementation of the State Program for 2015-2019 were considered and problematic issues requiring changes in regional policy were formulated. Based on the analysis, the authors presented a new approach to regional development, which will ensure macroeconomic stability based on high-tech industries (technology parks), educational and research clusters (corporations, universities and laboratories). To increase the efficiency of management of the territorial development of the Republic, systemic measures are
\end{abstract}

\section{Introduction}

The level and quality of life, as a complex socio-economic category, is a prerequisite and result of state regulation of territorial development. The integrated development of the regions is aimed at using the competitive advantages of each region. The processes of regionalization taking place in the economy have created the preconditions for the formation of a regional structure of industrial potential as an independent subsystem for managing the industrial development of Kazakhstan.

\section{Problem Statement}

Speaking about industrial potential, we note that their functionality is individual, since the composition and structure depend on regional specialization, education level, innovation

\footnotetext{
* Corresponding author: gulnara15-75@inbox.ru
} 
and economic potential. The spatial concentration of business entities and the territorial division of labor by regions determine the features of regional management to ensure and the possibility of their economic growth and development. The implementation of the State Program for the Development of the Regions of the Republic of Kazakhstan until 2020 became the initial stage of restarting the regional policy of the country, and made it possible to develop comprehensive measures to solve the problems of regional development [1].

To increase the role of regions in the development of business activity of business, state support for the innovation ecosystem is being implemented, which is carried out on the basis of the principle of decentralization [9]. This principle assumes that the regions independently form the regional industrial policy and finance activities on the basis of public-private partnerships. Such a policy contributes to the development of interregional competition in obtaining budgetary funding, and on this basis the formation of an effective regional system for managing industrial potential. At the same time, the budgets of local executive bodies include financing costs for the most promising investment projects and industrial infrastructure (On amendments and additions to the Resolution of the Government of the Republic of Kazakhstan dated December 7, 2017)

\section{Research Questions}

When developing the State Program for the Development of the Regions of the Republic of Kazakhstan until 2020, the materials of the applied research "Expert and analytical support for improving regional policy in terms of conceptual adjustment of the provisions of the Program for the Development of Regions" were used[11]. The assessment of the State program was carried out on the basis of the Methodology for assessing the Strategic Development Plan of the Republic of Kazakhstan and state programs.

\subsection{Formation of the industrial potential of certain regions of Kazakhstan}

In total, funds in the amount of 1,741.5 billion tenge were allocated for the implementation of the State Program for 2015-2019, including:

- at the expense of the Republican Budget 770.2 billion tenge;

- at the expense of the National Fund 588.4 billion tenge;

- at the expense of the Local budgets 295.5 billion tenge;

- at the expense of the Extra-Budgetary Funds (funds of enterprises) 87.5 billion tenge.

Table 1. Dynamics of the volume of financing of the State program by source of financing, billion tenge

\begin{tabular}{|l|c|c|c|c|c|}
\hline \multirow{2}{*}{ Source of financing } & \multicolumn{5}{|c|}{ Funding for years, billion tenge } \\
\cline { 2 - 6 } & $\mathbf{2 0 1 5}$ & $\mathbf{2 0 1 6}$ & $\mathbf{2 0 1 7}$ & $\mathbf{2 0 1 8}$ & $\mathbf{2 0 1 9}$ \\
\hline Republican budget & 177,93 & 114,35 & 101,40 & 129,89 & 232,59 \\
\hline National Fund & 206,78 & 326,45 & 51,64 & - & - \\
\hline Local budget & 43,94 & 29,88 & 73,67 & 81,30 & 64,73 \\
\hline Extra-Budgetary Funds & 0,64 & 19,43 & 25,82 & 32,27 & 8,79 \\
\hline Total & 429,29 & 490,12 & 252,54 & 243,46 & 306,11 \\
\hline
\end{tabular}

The development amounted to 1,728.8 billion tenge, or 99.3\% (Table 1). If we consider the structure of funding sources, a number of conclusions can be drawn (Table 2). 
Table 2. Financing structure of the State program by source of financing, $\%$

\begin{tabular}{|l|c|c|c|c|c|}
\hline \multirow{2}{*}{\multicolumn{1}{|c|}{ Source of financing }} & \multicolumn{5}{|c|}{ Share by years, \% } \\
\cline { 2 - 6 } & $\mathbf{2 0 1 5}$ & $\mathbf{2 0 1 6}$ & $\mathbf{2 0 1 7}$ & $\mathbf{2 0 1 8}$ & $\mathbf{2 0 1 9}$ \\
\hline Republican budget & 41,44 & 23,33 & 40,15 & 53,35 & 75,98 \\
\hline National Fund & 48,16 & 66,61 & 20,45 & - & - \\
\hline Local budget & 10,24 & 6,1 & 29,17 & 33,39 & 21,15 \\
\hline Extra-Budgetary Funds & 0,22 & 3,96 & 10.23 & 13,26 & 2,87 \\
\hline Total & 100 & 100 & 100 & 100 & 100 \\
\hline
\end{tabular}

As can be seen from the presented calculations, in the structure of funding sources for the State Program over the five years there have been major changes, including an increase in the share of the Republican budget from 41 to $76 \%$, the share of the local budget from $10.2 \%$ to $21.15 \%$, an increase in the share of extra-budgetary funds. more than 10 times. Such an increase in the named sources was due to the fact that the funds from the National Fund were reduced by more than 2 times by 2017, and since 2018 the financing of the State Program from this fund was stopped. An encouraging factor in the development of the economy is the growth of extra-budgetary sources, including through public-private partnerships (On approval of the State Program for the Development of Regions until 2020, 2018).

State regulation of territorial development and the formation of the industrial potential of individual regions of Kazakhstan is supported by funding from the republican budget. Of the total amount of the republican budget, the volume of additionally allocated budget funds for new events in accordance with the instructions of the Elbasy, given at the congress of the NurOtan party on February 27, 2019, amounted to 233.7 billion tenge, and another 57.3 billion tenge was allocated for implementation the project "Auyl - El besigi" and the development of the outskirts of large cities. However, in 2019, the development amounted to 306.1 billion tenge or $99.6 \%$. The main reasons for non-disbursement of funds are:

- cost savings based on the results of public procurement;

- lagging behind the work schedule;

- adjustment of projects;

- postponement of work execution;

- revision of the work plan;

- litigation due to non-fulfillment of contractual obligations by contractors and others.

Result indicator "Increase in the volume of attracting investments in fixed assets (excluding budget funds), in the context of regional centers such as Nur-Sultan, Almaty and Shymkent have not been reached.

In 2019, the volume of attracted investments in fixed assets amounted to 3,050.1 billion tenge against the plan of 3,146.6 billion tenge, and compared to 2018 (3,458.4 billion tenge) the reduction amounted to 408.3 billion tenge, or $11.8 \%$. The reasons for not achieving the performance indicator and reducing the volume of investments are quite varied and are related to the specifics of the region. The following can be distinguished:

- in the Atyrau region - with the plan of 841.7 billion tenge, the volume of attracted investments amounted to 370.8 billion tenge in 2019. That is, the decrease in comparison with 2018 amounted to 99.7 billion tenge, which was the result of the completion of investment in the reconstruction and construction of a deep oil refining complex of the LLP "Atyrau Refinery", a power plant of the LLP "Karabatanutilitysolutions", as well as the postponement of the completion of the construction of a gas-chemical complex of the LLP "KPI" from 2018-2019 to 2021-2024; 
- in Nur-Sultan - in 2019, investments in fixed assets amounted to 775.0 billion tenge, while the plan was 801.0 billion tenge. This means that the reduction in comparison with 2018 amounted to 129.7 billion tenge due to the phased completion of the construction of the large "Abu Dhabi Plaza" project and the lack of funding for the project "New transport system of Astana. LRT ";

- in Shymkent, there was a reduction due to the completion of work on the modernization of the LLP "PetroKazakhstan Oil Products" in 2018;

- in the Zhambyl region, 2 projects planned under the state program of industrial and innovative development have not been put into operation: LLP "KISC" (reconstruction of the foundry) and LLP "Taraz valve plant" (construction of a new workshop for the production of construction fittings) (Order of the Minister of National Economy of the Republic of Kazakhstan "On Some Issues of the State Planning System in the Republic of Kazakhstan", 2018).

\subsection{Results of the implementation of the State program}

The main results of the implementation of the State Program for 2015-2019 include the following:

- Development of functional urban areas (18 FUA) is designated as a "driver" of economic growth in regions (based on the experience of urban development in OECD countries).

- As part of the execution of the order of Elbasy, given at the XVIII Congress of the "NurOtan" party, the project "Auyl - El Besigi" is being implemented.

- Approved the Methodology for the development of Strategies for the development of large cities in the country until 2050.

- Strategies for the development of large cities in the country until 2050 were approved.

- Implemented 123 projects for the development of engineering infrastructure in singleindustry towns.

- 57 "anchor" investment projects were implemented in monotowns of Almaty, Karaganda, Kostanay, Mangistau, Pavlodar and Turkestan regions.

- Implemented 9.4 thousand projects for financial support of local government.

- 55 projects for the development of social and engineering infrastructure of residential areas of the outskirts of large cities and the settlements adjacent to the capital of the Akmola region were implemented (in 2019).

- Implemented 1,107 projects for the construction / reconstruction of water supply and sewerage systems in cities and villages.

- Implemented 74 projects for the construction / reconstruction of group water lines.

- Commissioned 565 facilities for water supply and sewerage systems in cities and villages.

- The reserves of underground waters of 2,098 villages were provided, reserves for 98 deposits of underground waters were additionally explored and re-approved.

- The mechanism for the development of water supply systems has been strengthened with the transition to rational and efficient ways of water supply for the population (Investment as a Key Driver of Kazakhstan's Economic Growth: New Enterprises, Advanced Technologies and Job Creation, 2019).

However, the effectiveness of the implementation of the State Program was an average level of 2.9 points.

This is due to the fact that during the implementation of the State program the following problematic issues took place:

- frequent changes and additions to the program document;

- a low level of achievement of the planned target indicators in the implementation of measures was formed due to the impossibility of continuous monitoring and control over the implementation of the provisions of the State Program in the originally approved 
version. (State program of industrial and innovative development of the Republic of Kazakhstan for 2020 - 2025, 2019).

\section{Purpose of the Study}

The purpose of the study was to analyze and assess the directions of state support for the industrial policy of the regions of Kazakhstan based on the principle of decentralization

Before the adoption of the program of industrial and innovative development of Kazakhstan for 2020-2025, the entire infrastructure of Kazakhstan included entities created with the participation of state budget funds (republican, local budgets, funds of organizations with state participation), as well as service development institutions created by the state [2].

However, this infrastructure did not activate the interaction between its subjects and did not implement the function of providing a full range of services for the participants in the innovation process. Industrial infrastructure organizations did not provide the required pace of sustainable development of Kazakhstan for a number of reasons:

- territorial dispersal of regions with industrial potential and insufficient coverage of the information infrastructure of the regions;

- the need to create an infrastructure to support both sectoral and regional development processes;

- the need to comply with the principle of expediency of costs and their compliance with the possibilities of the state budget;

Taking into account the relevance of the development of the country's regions, it is necessary to continue the implementation of the State Program aimed at the formation of regional policy. In this regard, the continuation of the implementation of the main directions of regional policy is enshrined in the State Program for the Development of Regions for 2020-2025 approved by the Government Decree of December 29, 2019 No. 990 (On approval of the State Program for the Development of Regions for 2020 - 2025, 2019)

The goal and objectives of the new program are consonant with the main directions of the long-term strategy of the country's economic development and are a logical continuation of the previous program.

It is important to pay special attention to single-industry towns through city-forming enterprises.

For the full disclosure of the potential of the villages, further implementation of the "Auyl - El Besigi" project is necessary. In the current year within the framework of this Program are implemented:

- 920 projects in 216 villages (184 reference, 32 satellite, 329 housing and communal services projects,

- 223 social infrastructure projects,

- 368 transport infrastructure projects.

In general, the project "Auyl - El Besigi" will allow modernizing the infrastructure of 3 thousand villages, achieving the requirements of the system of regional standards for villages and, accordingly, improving the quality of life of 6 million villagers.

The financial capabilities of rural districts are expanding through the transfer of certain types of taxes and payments. At the same time, local residents are actively involved in the process of distributing funds. For this, a new Concept of Local Self-Government is being developed. It is supposed to provide for the election of akims of rural districts, as well as the expansion of the powers of maslikhats. 


\section{Research Methods}

The theoretical basis of the scientific research was the theoretical concepts and methodological developments of domestic and foreign scientists on the problems of regional development, and in addition, general scientific methods were used, including the system approach, network theory, the method of expert assessments, the classification of species, the comparison method, methods of quantitative analysis and some others.

Periodic, statistical, analytical and translated literature in the direction of research was used as information resources.

\section{Findings}

The main task of Kazakhstan is the full disclosure of its industrial potential, the development of new redistributions in ferrous and nonferrous metallurgy, petrochemistry, mechanical engineering, production of building materials, food products and other sectors. For this, it is necessary to implement a set of measures to introduce new technologies, attract strategic investors, and improve the qualifications of Kazakhstani specialists. The state should focus on creating a surplus supply of quality industrial infrastructure in convergence with spatial development. In general, it is necessary to develop a strategy for the development of regions on the basis of high-tech industries (technology parks), educational and research clusters (corporations, universities and laboratories). In this direction, measures are already being taken to complete the construction of the infrastructure of special economic zones (hereinafter - SEZ) and industrial zones (hereinafter - IZ) on the basis of industrial regional centers with an increase in the efficiency of their management. On the territory of promising SEZs and IZs, ground infrastructure is being created according to the "ready-built-factories" principle, and the participants have the opportunity to test and implement technological solutions, place technological platforms, create centers of competence, model production facilities and incubators. The mechanism for the construction of IZ and industrial parks on the principle of public-private partnership has been developed.

To systematize the provision of direct financial support on the basis of existing development institutions, an Industry Development Fund was created. It will provide direct support through equity entry and the provision of loans at an interest rate of no more than $3 \%$ per annum in tenge for the final borrower.

In order to increase the efficiency of regional management to ensure the self-sufficiency of the sectors of the economy, qualitatively new approaches have been developed for the development of industries with high added value in the agro-industrial complex and the manufacturing industry based on the available raw material base, the treated attraction of investments and active promotion of exports. To ensure food security in the agro-industrial complex, it is planned to implement 380 investment projects with the involvement of more than 5 trillion. tenge investment. This will fully provide the domestic market with socially significant food products at the expense of its own production.

At the same time, great attention is paid to the development of efficient production of goods with stable internal and external demand, logistical availability of sales and, as a result, great potential for increasing production.

As part of the further industrialization of the regional economy, tasks have been set aimed at ensuring the growth of production by 1.5 times in the manufacturing industry $(2.4$ trillion tenge in 2020), in the petrochemical industry by 9 times (from 231 thousand to 2 million. tons of products) with the attraction of about 15 billion dollars (Site of journal "Forbes Kazakhstan", 2020). USA for 5 years, while being considered as promising export markets: China, Russia, Belarus, Georgia, Central Asia, etc. 


\section{Conclusion}

In order to further high-quality implementation of the State Program, it is proposed to interested state bodies and akimats of regions, years. Nur-Sultan, Almaty and Shymkent, as well as other organizations:

- to improve the quality of planning and forecasting target indicators and indicators of the effectiveness of regional management results;

- when planning budget expenditures within the framework of the State Program, proceed from the real need for financed activities and their compliance with the republican tasks of the country's socio-economic development;

- to strengthen control over financial discipline when spending budget funds allocated for the development of regions, over the effective distribution and use of funds from the republican budget, to ensure the completeness and quality of the use of funds allocated for the implementation of the State Program, and also to consider the possibility of increasing the volume of project financing at the expense of local budgets and extrabudgetary funds; - on an ongoing basis, carry out work to identify and eliminate corruption and other types of risks in the implementation of measures of the State Programs.

A new approach to regional development will help manage the urbanization process, ensure the phasing of "migration waves", avoid overpopulation and social tension in large cities. To increase the efficiency of the implementation of the State Program, systemic measures should be implemented:

- to increase the level of industrialization and to unlock the industrial potential of the south and southeastern part of the country;

-. to attract investments in the construction of petrochemical complexes and the creation of new production cycles of high processing value in the western regions;

- to diversify the economy of the central, northern and northeastern regions, where large metallurgical enterprises prevail.

Within the framework of ensuring macroeconomic stability, further implementation of countercyclical territorial policy is required, which ensures the balance and alignment of regions in terms of socio-economic indicators.

\section{References}

1. G.A. Abzalbek, Ekonomika Central'noj Azii - Economy of Central Asia, 5(1) (2021)

2. T.A. Bjorn, H.L. Helen Smith, C. Oughton, Regional Innovation Systems: Theory, Empirics and Policy Regional Studies, 45(7), 875 (2011)

3. Gosudarstvennaya programma industrial'no-innovacionnogo razvitiya Respubliki Kazahstan na 2020 - 2025 gody, https://adilet.zan.kz/rus/docs/P1900001050

4. Investicii kak klyuchevoj drajver rosta kazahstanskoj ekonomiki: novye predpriyatiya, peredovye tekhnologii i sozdanie rabochih mest, https://primeminister.kz/ru/news/reviews/investicii-kak-klyuchevoy-drayver-rostakazahstanskoy-ekonomiki-novye-predpriyatiya-peredovye-tehnologii-i-sozdanierabochih-mest [in Russian].

5. O vnesenii izmenenij i dopolnenij v postanovlenie Pravitel'stva Respubliki Kazahstan ot 7 dekabrya 2017 goda № 823 «O realizacii Zakona Respubliki Kazahstan «O respublikanskom byudzhete na 2018 - 2020 gody». Postanovlenie Pravitel'stva Respubliki Kazahstan ot 5 maya 2018 goda № 245, https://cdb.kz/sistema/pravovayabaza/o-vnesenii-izmeneniy-i-dopolneniy-v-postanovlenie-pravitelstva-respublikikazakhstan-ot-7-dekabrya-2017-goda-823-o-realizatsii-zakona-respubliki-kazakhstano-respublikanskom-byudzhete-na-2018-2020-gody-/ 
6. Ob utverzhdenii Gosudarstvennoj programmy razvitiya regionov do 2020 goda, http://adilet.zan.kz/rus/docs/P1800000767

7. Ob utverzhdenii Gosudarstvennoj programmy razvitiya regionov na 2020 - 2025 gody, http://adilet.zan.kz/rus/docs/P1900000990

8. Prikaz Ministra nacional'noj ekonomiki Respubliki Kazahstan «O nekotoryh voprosah Sistemy gosudarstvennogo planirovaniya v Respublike Kazahstan» ot 19 fevralya 2018 goda № 64, https://adilet.zan.kz/rus/docs/V1800016493

9. S.B. Rudich, Economic Sciences, 41 (2017)

10. Sajt zhurnala «Forbs Kazahstan», https://forbes.kz/process/economy/industrializatsiya _v_kazahstane_pervyie_itogi_i_novyie_vyizovyi

11. Sh. Kajmoldina, Sh. et al, Journal of Economy and Finance, 3-4, 5 (2020) 